Z Gerontol Geriat 2021 · 54:161-166 https://doi.org/10.1007/s00391-020-01718-1 Received: 20 September 2019

Accepted: 5 March 2020

Published online: 23 March 2020

(c) The Author(s) 2020

\section{Fabian Hutmacher}

Lehrstuhl für Psychologie VI, Universität Regensburg. Correspondence concerning this article should be addressed to Fabian Hutmacher, Lehrstuhl für Psychologie VI, Universität Regensburg, Regensburg, Germany

\title{
Understanding the self of people with dementia
}

\section{Psychological and philosophical considerations}

both share the assumption that people with dementia have a severely impaired self, either because they relive the seemingly innocent state of childhood or because they are practically dead already, zombies without inner depth. On closer examination though, things turn out to be more complicated and complex. As the first section demonstrates, there are different notions of self, among which the narrative, remembering self is only one. Thus, although the narrative self may be impaired in people with dementia, this does not mean that the self of people with dementia is a blank slate, a self without history or depth. Based on this idea, the second section describes and discusses the depths of the self of people with dementia, while the third and last section tentatively explores some conclusions that can be drawn from these insights for engaging with people with dementia.

\section{Different notions of self} are storytellers and that the stories we tell define who we are [21]. Thus, at first sight, one may argue that the self of people with dementia is a severely fragmented and reduced self, which becomes more fragmented and reduced the more the disease progresses. Such an understanding of the self of people with dementia is in line with contemporary discourses on dementia, which often metaphorically depict dementia as a "return to childhood" or as "living death" [26]. While the first metaphor expresses a more positive evaluation of the disease than the latter,
Imagine listening to the recording of a symphony orchestra. Unfortunately, the disc has a scratch near the end, producing a shocking sound. Hearing that sound does not only make you cringe, it also overshadows the minutes before. When someone asks you whether you liked the recording, you may no longer think about the wonderful piece of music that you were listening to but rather about the horrible sound that disturbed you near the end. It seems that the sound ruined the whole experience; however, according to Kahneman [16], who uses this example to distinguish between two kinds of selves, the experiencing self and the remembering self, the scratch does not in fact ruin the whole experience. It ruins the memory of the experience, it ruins what the remembering self thinks about the experience when looking back on it, but not what the experiencing self perceived while listening to the music, i.e., while making the experience up until the shocking sound.

What Kahneman calls the experiencing self, has also been described as the core or minimal self, and what he defines as the remembering self, has also been characterized as the extended or narrative self(for an overview see, e.g., [11, 30]; for the historical origins see the distinction between "I" and "Me" by William James [14]). While the narrative, remembering self can be defined as the "more or less coherent self $[\ldots]$ that is constituted with a past and a future in the various stories that we and others tell about ourselves" [11, p. 231], the minimal, experiencing self is defined as the self which makes experiences in the present moment. What can we learn from this distinction in the case of people with dementia?

Although neither Kahneman nor the proponents of the distinction between a minimal and a narrative self explicitly refer to dementia in their writings, one could argue that dementia primarily affects the remembering self, i.e., the ability to put different experiences in context and to perceive different events as belonging to the same story, while the experiencing 
self remains largely unaffected. This idea fits well with the differentiation between vivre and se vivre introduced by Tatossian [29] to describe the state of mind of people with dementia. Following his line of thought, people with dementia are still aware of what is happening right now (vivre), but increasingly have problems with taking a distanced and reflective stance towards these momentary experiences (se vivre); however, this distinction should not be taken to the extreme for at least two reasons. First, people with dementia still show episodes of lucidity from time to time (see, e.g., [23]) or as Post [24] put it: "The reality is that until the very advanced and even terminal stage of dementia, the person with dementia will usually have sporadically articulated memories of deeply meaningful events and relationships ensconced in long-term memory" (p. 231). Secondly, people with dementia often seem to feel the need to locate themselves within time [22], indicating an urge to create stability and orientation reaching beyond the present moment [28]. As these two arguments demonstrate, claiming that the remembering self disappears completely in people with dementia would oversimplify the matter [15].

Nonetheless, these caveats do not touch upon the general idea that it is primarily the remembering self that is affected by dementia while the experiencing self remains largely intact; however, if the minimal, experiencing self plays such a crucial role in people with dementia, it seems advisable to take a closer look at the concept: how can it be characterized in more detail? Gallagher [11] for his part seems to believe, for instance, that there is not much detail to be added. For him, the minimal self is "the consciousness of oneself as an immediate subject of experience, unextended in time" (p. 15). The idea that the minimal, experiencing self is unextended in time, that it consists of nothing but the mineness, "that is, the fact that the experiences are characterized by a first-personal givenness that immediately reveals them as one's own" [30, p. 124], would imply that the self of a person with dementia is a self with no inner depth, were it not for the few fragments of the remembering self that still remain. In contrast, some authors have argued that the minimal, experiencing self is spatially-temporally structured and influenced by the history of the individual (see, e.g., $[10,27,30]$ ). But what does that mean?

\section{The depths of the experiencing self}

We do not only have semantic-conceptual memories, i.e. verbalizable memories about facts and ideas as well as our own lives, but also perceptual memories, i.e. memories of perceptual information that has reached our senses. Take the abovementioned example of listening to the recording of a symphony orchestra: You may know that you will like this specific recording because you are a fan of classical music or because the orchestra was conducted by your favorite conductor. In this case, you are using conceptual knowledge about your musical preferences. In a different situation, for example when driving on the highway and trying to select a radio station, you do not have to think about the different kinds of music that you like (and those that you dislike) in order to make a choice. You will just stop switching between different radio stations once you hear a piece of music that sounds familiar or pleasant to you. When referring to perceptual memories, Fuchs $[9,10]$ used the term body memory. According to him, there are six different forms of body memory, all of which he believes to be present in people with dementia, even in the later stages of the disease [10]. If this were true, the experiences of the minimal self and its reactions to these experiences would be guided by the prior life history of the individual. Thus, the minimal, experiencing self in people with dementia would indeed be a self with inner depth. The conclusions that can be drawn from this idea are discussed in the final section. First, let me describe the different forms of body memory and the way they are supposedly still present in people with dementia.

Procedural memory is memory for "patterned sequences of movement, well-practiced habits, skillful handling of instruments, as well as familiarity with patterns of perception" $[9$, p. 12]. People with dementia are able to handle everyday tools (e.g., a toothbrush) and to perform everyday actions (e.g., brushing their teeth) even when they have already forgotten the names of the tools. In fact, they may still be able to learn new procedures like dance moves [5, 25]. Situational memory is-as the name already suggests-memory for specific, well-known situations and places. A person now suffering from dementia who has been a football fan for his or her whole life, for instance, may still be able to enjoy the atmosphere in a football stadium and to cheer for the home team, although he or she may no longer be capable of recalling the name of the players or the football club. In a similar manner, people with dementia may still lower their voices when entering a church without being able to explain why this is considered to be the appropriate behavior or to navigate through their own home without being able to draw or to describe it properly (see e.g., [19]). The third form of body memory, intercorporeal memory, refers to the fact that our ways of interacting with people are shaped by our prior experiences in social situations. We know how to behave when someone is sad or happy, and we are able to sense whether someone wants to be left alone or would prefer a hug. In fact, people with dementia seem to be very sensitive to subtle changes in the atmosphere of the situation as well as the emotional state of the person they are interacting with and still show their own feelings and needs in their gestures and facial expressions long after they have lost the ability to express them verbally [10]. The fourth form of memory, incorporative memory, strongly resembles what Bourdieu [2] called the habitus. The habitus "denotes the entire social appearance of a person including his or her posture, manners, taste, clothing, attitudes and general way of life" [9, p. 16]. In this sense, people with dementia preserve their typical behavior when expressing emotions, showing interest or disgust, joy or shame. The fifth and sixth form of body memory, pain memory and traumatic memory are somewhat related: 
Unpleasant memories of the past largely influence our present thoughts and actions, even when we cannot verbalize them (see [3] for an early case study). This applies to both mildly painful and extremely painful, traumatic memories. A person with dementia, who had to hide in the basement of the house during one of the bombing raids of World War II, for instance, may refuse to go to the basement of the nursing home without being able to give their reasons for this behavior.

\section{The alterity of the self of people with dementia}

The self of people with dementia is not unextended in time: Although the remembering self may be gradually fading away, the remaining experiencing self is a self with inner depth, mirroring the life history of the individual. That is not meant to dispute the significant burdens, challenges, and difficulties that come with a dementia diagnosis for both the diseased person as well as family members and friends. Nevertheless, understanding the complexity of the self of people with dementia can help to counterbalance our bias towards the rational and intellectual understanding of who we are. $\mathrm{Hu}$ mans are not only storytellers; humans are also beings with an extremely rich and embodied inner perceptual world (for recent empirical studies with healthy subjects, see, e.g., $[12,13])$. This insight has a number of important implications for engaging with people with dementia. First, it would be shortsighted to describe people with dementia as being endangered of losing their self or even of “"unbecoming' a self” [8, p. 36]. The remembering self of people with dementia does indeed become increasingly fragmented during the course of the disease while the experiencing self does not or at least to a far smaller degree. Keeping this in mind seems to be of greatest importance as it has been shown that treating people with dementia as if they had already lost their sense of self, may work as a self-fulfilling prophecy, i.e. it may accelerate the disease [1, 17]. Second, losing the abilities of the remembering self, i.e. losing the ability to narrate one's

Z Gerontol Geriat 2021 · 54:161-166 https://doi.org/10.1007/s00391-020-01718-1

(c) The Author(s) 2020

\section{F. Hutmacher}

\section{Understanding the self of people with dementia. Psychological and philosophical considerations}

\section{Abstract}

Background. The ability to create and maintain an ongoing life narrative is a key characteristic of what makes us human; however, people with dementia lose this ability in the course of the disease. If the notion of having a self is intimately linked with being able to create and maintain a life narrative and if people with dementia tend to lose this ability, what kind of self do people with dementia still possess?

Objective and methods. Recent theories developed in psychology and philosophy suggest that at least two notions of the self have to be distinguished: the experiencing self and the remembering self. This distinction is applied to people with dementia.

Results. While the remembering self is impaired in people with dementia, their experiencing self remains relatively intact.
Critically, the experiencing self is a self with inner depth, mirroring the life history of the individual. Thus, the self of people with dementia is not unextended in time. Although people with dementia may have lost the ability to tell a story about their life, they are still able to express this story in their behavior.

Conclusion. Understanding the structure of the self of people with dementia can help guide interactions as well as the designing of appropriate interventions and environments. Moreover, realizing the inner depth of the self of people with dementia may help acknowledge their dignity and personhood.

Keywords

Dementia - Life story · Remembering self . Experiencing self $\cdot$ Body memory

\section{Das Selbst von Menschen mit Demenz verstehen. Psychologische und philosophische Überlegungen}

\section{Zusammenfassung}

Hintergrund. Die Fähigkeit, unser Leben als Geschichte zu erzählen, ist ein entscheidendes Merkmal dessen, was uns als Menschen ausmacht. Menschen mit Demenz verlieren diese Fähigkeit jedoch im Laufe der Krankheit. Wenn die Vorstellung, ein Selbst zu haben, eng mit der Fähigkeit verbunden ist, unser Leben als Geschichte zu erzählen und wenn Menschen mit Demenz dazu neigen, diese Fähigkeit zu verlieren, welche Art von Selbst besitzen Menschen mit Demenz dann noch? Ziele und Methoden. Aktuelle Theorien aus Psychologie und Philosophie legen nahe, dass mindestens zwei Vorstellungen des Selbst unterschieden werden müssen: das "erlebende Selbst" und das „erinnernde Selbst". Diese Unterscheidung wird auf Menschen mit Demenz angewendet. Ergebnisse. Während das erinnernde Selbst bei Menschen mit Demenz beeinträchtigt ist, bleibt das erlebende Selbst vergleichsweise unbeeinträchtigt. Entscheidend dabei ist, dass es sich beim erlebenden Selbst um ein Selbst mit innerer Tiefe handelt, das die Lebensgeschichte des Individuums widerspiegelt. Das Selbst von Menschen mit Demenz ist also nicht zeitlich unausgedehnt. Obwohl Menschen mit Demenz möglicherweise nicht mehr in der Lage sind, eine Geschichte über ihr Leben zu erzählen, können sie diese Geschichte immer noch in ihrem Verhalten ausdrücken.

Schlussfolgerung. Die Struktur des Selbst bei Menschen mit Demenz zu verstehen, kann dabei helfen, Interaktionen zu lenken sowie geeignete Interventionen und Lebensumwelten zu entwerfen. Darüber hinaus kann ein Verständnis für die innere Tiefe des Selbst von Menschen mit Demenz dazu beitragen, ihre Würde und ihr Personsein anzuerkennen.

Schlüsselwörter

Demenz - Lebensgeschichte · Erinnerndes Selbst · Erlebendes Selbst · Leibgedächtnis 
own life, probably scares many people. It does so because we tend to think of ourselves as storytellers. Acknowledging the importance of body memory can help us to correct this bias and to perceive the perspective of people with dementia as a perspective in it's own right. This has important ethical consequences: when living with dementia is characterized as a radically different state of mind, centered around the experiencing rather than the remembering self, and not so much or at least not solely as a deficient, deteriorated condition, there is reason to believe that terms like autonomy and personhood are still meaningful and that the possibility of encountering other people remains of vital importance, even for people with later stage dementia. Third, our notion of well-being is dominated by the perspective of the remembering self (see [16]): Whether we are happy with our life largely depends on the way we evaluate our life as a whole. For people with dementia, however, the experiential dimension of well-being may become more important. Thus, although the loss of the remembering self may be experienced as negative by people with dementia, living with dementia does not necessarily mean leading an unhappy life. Although symptoms of depression and anxiety are admittedly quite common among people with dementia, it can be shown that even "those who are, from a cognitive standpoint, severely demented" [18, p. 269] can and do experience well-being. Fourth, the shift from the remembering to the experiencing self needs to result in different kinds of interactions with people with dementia. In fact, recognizing and accepting the person's reality instead of trying to correct it is one of the core principles in person-centered dementia care (for recent reviews see, e.g., $[6,20]$ ). Forcing a narrative upon people with dementia, which they cannot relate to, either because they have forgotten that this narrative used to be the narrative of their life or because this narrative has simply lost its importance, is frustrating for all people involved. Instead, it seems important to validate the momentary feelings, needs, and perceptions of the individual. An interesting concept in this respect is the so-called companionship of themes of being (see, e.g., [4]). Fifth, the knowledge about the structure of the self of people with dementia can inform the development of adequate interventions and environments. The architecture of nursing homes, for instance, should be and is in fact adjusted to the needs and perceptual habits of people with dementia [7]. Besides general rules of thumb regarding the design of well-suited environments, it seems important to acquire profound knowledge about the individual person with dementia. Although people with dementia may benefit from sensory stimulation and from a rich perceptual environment in general, they will probably benefit even more when the stimulation is aligned with their prior sensory experiences and present preferences. Thus, knowing the person with dementia, i.e., knowing past and present beliefs and needs, likes and dislikes, is another aspect in person-centered dementia care for a good reason.

In short, dementia is neither a return to childhood nor a living death. Although the disease disrupts well-established ways of interacting with each other and thus profoundly changes the relationship between the diseased person and his or her family and friends, the self of people with dementia is not a blank slate. Rather, people with dementia still have access to a complex life history.

\section{Practical conclusion}

Impairments of the remembering
self do not imply that people with
dementia possess only a minimal self
with no inner depth. Rather, their
experiencing self mirrors the story of
their lives, which they may no longer
be able to express verbally.
- Personhood is not bound to the
ability to explicitly recall one's past
in a coherent manner. Although the
self of people with dementia changes
profoundly, they are not unbecoming
a self-an idea that is well in line with
the principles of person-centered
dementia care.
People with dementia may benefit
from sensory stimulation and from
a rich perceptual environment, and
especially from an environment that

is aligned with the sensory history of their lives.

- When trying to get in touch with people with dementia, it may be advisable, especially in the later stages of the disease, to do so by focusing on bodily interactions, present needs and shared perceptions.

\section{Corresponding address}

\section{Fabian Hutmacher}

Lehrstuhl für Psychologie VI, Universität Regensburg. Correspondence concerning this article should be addressed to Fabian Hutmacher, Lehrstuhl für Psychologie VI, Universität Regensburg

Universitätsstraße 31, 93053 Regensburg, Germany

fabian.hutmacher@ur.de

Funding. Open Access funding provided by Projekt DEAL.

\section{Compliance with ethical guidelines}

Conflict of interest. F. Hutmacher declares that he has no competing interests.

For this article no studies with human participants or animals were performed by any of the authors. All studies performed were in accordance with the ethical standards indicated in each case.

Open Access. This article is licensed under a Creative Commons Attribution 4.0 International License, which permits use, sharing, adaptation, distribution and reproduction in any medium or format, as long as you give appropriate credit to the original author(s) and the source, provide a link to the Creative Commons licence, and indicate if changes were made. The images or other third party material in this article are included in the article's Creative Commons licence, unless indicated otherwise in a credit line to the material. If material is not included in the article's Creative Commons licence and your intended use is not permitted by statutory regulation or exceeds the permitted use, you will need to obtain permission directly from the copyright holder. To view a copy of this licence, visit http://creativecommons.org/licenses/by/4.0/.

\section{References}

1. Bosco A, Schneider J, Coleston-Shields DM, Orrell M (2018) Dementia care model: Promoting personhood through co-production. Arch Gerontol Geriatr 81:59-73

2. Bourdieu P (1990) The logic of practice. Stanford University Press, Stanford

3. Claparède E(1911) Reconnaissance et moitié. Arch Psychol 11:79-90

4. Ehret S (2009) Ich werde wieder lebendig. Personale Geschehensordnung und Daseinsthematische 
Begleitung bei Menschen mit Demenz. Südwestdeutscher Verlag für Hochschulschriften, Saarbrücken

5. Eldridge LL, Masterman D, Knowlton BJ (2002) Intact implicit habit learning in Alzheimer's disease. Behav Neurosci 116:722-726

6. Fazio S, Pace D, Flinner J, Kallmyer B (2018) The fundamentals of person-centered care for individuals with dementia. Gerontologist 58:S10-S19

7. Feddersen E, Lüdtke I (2014) Lost in space: architecture and dementia. Birkhäuser, Basel

8. Fontana A, Smith RW (1989) Alzheimer's disease victims: the "unbecoming" of self and the normalization of competence. Sociol Perspect 31:35-46

9. Fuchs $T$ (2012) The phenomenology of body memory. In: Koch S, Fuchs T, Summa M, Müller C (eds) Body memory, metaphor and movement. John Benjamin, Amsterdam, pp 9-22

10. Fuchs $T$ (2018) Leiblichkeit und personale Identität in der Demenz. Dtsch Z Philos 66:48-61

11. Gallagher S (2000) Philosophical conceptions of the self: implications for cognitive science. Trends Cogn Sci 4:14-21

12. Hutmacher F, Kuhbandner C (2018) Long-term memory for haptically explored objects: fidelity, durability, incidental encoding, and cross-modal transfer. Psychol Sci 29:2031-2038

13. Hutmacher F, Kuhbandner C (2019) Detailed longterm memory for unattended, irrelevant, and incidentally encoded auditory information. J Exp Psychol Gen 149(2):222-229

14. James W (1890) The principles of psychology. Volume one. Dover, New York

15. Jungert M (2018) "Ich habe mich sozusagen selbst verloren" - Biographische Identität, autobiographisches Gedächtnis und Alzheimer-Demenz. ZPraktPhilos 5:133-152

16. Kahneman D (2011) Thinking, fast and slow. Farrar, Straus and Giroux, New York

17. Kitwood T (1990) The dialectics of dementia: with particular reference to Alzheimer's disease. Ageing Soc 10:177-196

18. Kitwood T, Bredin K (1992) Towards a theory of dementia care: personhood and well-being. Ageing Soc 12:269-287

19. Liu L, Gauthier L, Gauthier S (1991) Spatial disorientation in persons with early senile dementia of the Alzheimer type. Am J Occup Ther 45:67-74

20. Manthorpe J, Samsi K (2016) Person-centered dementia care: current perspectives. Clin Interv Aging 11:1733-1740

21. McAdams DP, McLean KC (2013) Narrative identity. Curr Dir Psychol Sci 22:233-238

22. Minkowski E (1933) Le temps vécu. Études phénoménologiques et psychopathologiques. PUF, Paris

23. Normann HK, Asplund K, Karlsson S, Sandman PO, Norberg A (2006) People with severe dementia exhibit episodes of lucidity. A population-based study. J Clin Nurs 15:1413-1417

24. Post SG (2006) Respectare: moral respect for the lives of the deeply forgetful. In: Hughes $J C$, Louw SJ, Sabat SR (eds) Dementia: mind, meaning, and the person. Oxford University Press, Oxford, pp 223-234

25. Rösler A, SeifritzE, Kräuchi K, Spoerl D, Brokuslaus I, Proserpi SM, Gendre A, Savaskan E, Hofmann M (2002) Skill learning in patients with moderate Alzheimer's disease: a prospective pilot-study of waltz-lessons. Int J Geriatr Psychiatry 17:1155-1156
26. Schweda M, Jongsma K (2018) „Rückkehr in die Kindheit" oder "Tod bei lebendigem Leib"? Ethische Aspekte der Altersdemenz in der Perspektive des Lebensverlaufs. Z Prakt Philos 5:181-206

27. Summa M (2011) Zwischen Erinnern und Vergessen. Implizites Leibgedächtnis und das Selbst am Beispiel der Demenz-Erkrankungen. Phänomenol Forsch 2011:155-174

28. Summa M, Fuchs T (2015) Self-experience in dementia. Riv Internazionale Filos Psicol 6:387-405

29. Tatossian A (1987) Phénoménologie des états démentiels. Psychol Med 19:1205-1207

30. Zahavi D (2005) Subjectivity and selfhood. Investigating the first-person perspective. MIT Press, Cambridge, London

\section{Gestörte Protein-Balance verursacht grauen Star}

Der graue Star ist die häufigste Augenerkrankung beim Menschen. Die genauen Prozesse bei der Entstehung der Krankheit sind allerdings noch nicht vollständig aufgeklärt. Ein Forschungsteam hat nun herausgefunden, dass die Zusammensetzung der Proteinlösung eine entscheidende Rolle spielt.

Die Zellen der Augenlinse bestehen aus einer hoch konzentrierten, normalerweise klaren Proteinlösung. Wenn das Gleichgewicht der Proteine in der Linse gestört ist, verklumpen diese miteinander und die Augenlinse trübt sich, der graue Star (Katarakt) entsteht.

Die gängige Lehrmeinung war bisher, dass nur die defekten Proteine im Auge miteinander reagieren und verklumpen. Doch Wissenschaftler*innen konnten nun an Mäusen mit genetischen Katarakten zeigen, dass dies nicht der Fall ist. Die mutierten, instabilen Proteine sind im Gegenteil gar nicht in der Augenlinse vorhanden, sie werden sofort abgebaut. Stattdessen verklumpen die restlichen Proteine miteinander. Dass aus diesen Erkenntnissen entwickelte Modell ist, dass die Balance der verschiedenen Proteine, also ihr Verhältnis zueinander wichtig ist. Wenn eins dieser Bestandteile fehlt, interagiert der Rest und verklumpt. Die neuen Erkenntnisse sind ein wichtiger Schritt bei der Suche nach neuen Behandlungsmethoden. Zunächst muss jedoch gezeigt werden, dass das vorgeschlagene Modell auch für menschliche Augenlinsen zutrifft.

Originalpublikation: Schmid, P.W.N., Lim, N.C.H., Peters, C. et al.: Imbalances in the eye lens proteome are linked to cataract formation. Nat Struct Mol Biol 28, 143-151 (2021). https://doi.org/10.1038/s41594020-00543-9

Quelle: Technische Universität München, https://www.tum.de/ 
Hier steht eine Anzeige.

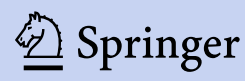

